\title{
Critical success factors for offshoring of enterprise resource planning (ERP) implementations
}

\author{
Rajneesh Chauhan, Rajeev Dwivedi and Arun Mohan Sherry \\ Institute of Management Technology (CDL), Ghaziabad, India
}

\section{Abstract}

\begin{abstract}
Background: In recent years, offshoring enterprise resource planning (ERP) implementation has been an emerging trend in the field of offshoring information technology (IT). However, both ERP implementations and IT offshoring are fraught with risks, and when both ERP implementation and IT offshoring happen together, the risks become even more pronounced. Therefore, it is important to understand and identify the issues of ERP implementation in an offshoring situation. Objectives: The purpose of this paper is to highlight the key factors that enable successful offshoring ERP implementation from the client and the vendor perspective. Methods/Approach: The paper uses literature as a basis for identifying a critical success factor, data collected through semi-structured interviews with ERP managers at various levels of the subject organizations, and eventually their analysis. Results: The findings of the paper reveal that various factors are critical while implementing offshoring ERP. They include: offshoring partnership, project management, project team composition, people issues, communications and compliance of the onsite team composition. It is also noticed that ten factors are grouped into three categories: the client side, the vendor side, and both. Conclusions: Organizations are currently undertaking or considering the offshoring ERP implementation particularly from India. This paper will enable them to understand the possible challenges and areas of offshoring the ERP implementation program. The value and originality of the paper comes from the fact that up to now, ERP implementation in offshoring has not been comprehensively explored. This research provides a complete understanding of the critical success factors from the client, the vendor or both the client and the vendor perspective. It also enables researchers to analyse ili rethink ili review offshoring in different service areas.
\end{abstract}

Keywords: Enterprise Resource Planning (ERP), Implementation, Offshoring, Critical Success Factors JEL Classification: M31, F23

Paper type: Research article

Recieved: 23, April, 2012

Revised: 4, June, 2012

Accepted: 26, June, 2012

Citation: Chauhan, R., Dwivedi, R., Sherry, A.M. (2012). "Critical success factors for offshoring of enterprise resource planning (ERP) implementations", Business Systems Research, Vol. 3, No. 1, pp. 4-13.

DOI:10.2478/v10305-012-0001-5

Acknowledgement: The authors would like to thank Institute of Management Technology (IMT) and National Law University (NLU) for the guidance and support.

\section{Introduction}

Outsourcing can be defined as hiring outside company to perform the task that otherwise performed internally by the company. Insourcing is when a company ceases to contract a business function and begins to perform it internally. Insourcing is the opposite of outsourcing. According to various reports, global outsourcing industry, including offshoring and on shoring, is estimated to touch approximately US $\$ 500$ billion in 2011-12. Offshoring describes the relocation of business processes from one country to another. India has approximately $43 \%$ market share in global offshoring followed by China and Philippines. Kaka (2009) said that "India's offshoring industry is strengthening and even expand its global market share, but only if it learns to innovate". Theoretical background suggests that cost-saving advantage is the primary 
reason for offshoring business processes from India. ERP applications generate a lot of interest as they bring simultaneous operational efficiencies, better decision making and a platform for business innovation. However, even after decades of being around, ERP implementations are still fraught with risks and failures. Against the backdrop of this, while on one side ERP applications were changing the way businesses are run, concurrently offshoring of IT services was also picking up and changing the way IT organizations are run. IT Services were getting offshored and the value chain that delivered IT services was getting transformed and global.

Offshoring has tremendous benefits and hence has become an industry changer. However, offshoring is also fraught with risks and uncertainties. Against this background, there are organizations that are trying to marry ERP implementations and offshoring. This opens up immense possibilities of gains but at the same time risks get compounded as both ERP implementations and offshoring are fraught with uncertainties. It is in this context that this study has been conducted on critical success factors for offshoring of ERP Implementations. For this research the geography under consideration is Switzerland, the offshoring location is India, the ERP under consideration is the flagship ERP of SAP and Oracle. Further, since, most of the offshoring that happens is outsourced hence the scope of research is restricted to offshored outsourced scenarios only.

There have been multiple studies conducted on critical success factors of ERP implementations. Likewise several studies have been conducted on critical success factors of offshoring. Both (ERP and Offshoring) are covered separately in most of the studies. However, there is limited material which can address the critical success factors of Offshoring and ERP implementation together.

The objective of the paper is to explore and understand the areas of concern in offshoring ERP implementation, which raise the question: $R Q 1$ : To identify the critical success factors in ERP implementation in offshoring situation where clients are from Switzerland and vendors are from India. Further, our goal is to understand in such programs, what would be the major role of the client and vendor, which raised our second research question: RQ2: To evaluate the role of client/vendor/client-vendor in offshoring ERP implementation programs.

\section{Literature Review}

ERP applications can be defined as business applications package that can be configured to seamlessly integrate the business processes of an organization across the various functions of a business. ERP is a largely pre built, configurable platform that can be used by the organization to run and integrate all its functions like production, purchasing, sales, logistics, finance, human resources etc.

ERP has evolved over the years into its present shape and scale. The journey started with manufacturing industries as applications for inventory control. As the requirements grew, it evolved into material requirements planning (MRP), then into MRP II i.e. manufacturing resources planning (Kumar and Hillegersberg, 2000). The next step for evolution was late 1980's when ERP applications into beginning. Today, these applications have evolved into complex and big ERP applications that not only have an inward focus inside the organization but also an outward focus on the partner organizations that form a part of the overall business ecology.

ERP applications bring along not only the benefits of integration, operational efficiencies, better decision making capabilities but also gives organizations an opportunity to relook, innovate and transform their business process. ERP systems are expected to reduce costs by improving efficiencies through computerization and enhance decision-making by providing accurate and timely enterprise-wide information (Poston and Grabski, 2001). They reflect an innovative business strategy, as ERP adoption involves business process improvement, best practices implementation, intra enterprise integration and inter-enterprise coupling (Hunton et al., 2003). The lure of these benefits is such that more and more organizations are leaving custom built applications and going for readymade and configurable ERP applications.

It has been said in various studies that ERP packages are complex to implement. The failure rates are high and not many organizations are able to deploy them successfully. Various studies have been conducted, though the exact percentage might differ but almost fifty per cent of ERP implementations do not deliver the results expected from them. In the Gioia (2002) survey, 51 \% viewed their ERP implementations as unsuccessful. The Conference Board survey interviewed executives in 117 companies that attempted ERP implementations and $40 \%$ of the projects failed to achieve their business case within one year of going live (Cooke et al., 2001).

Given the challenges and failures in ERP implementations, critical success factors for ERP implementations have been an object of research over the decades.

Early research on ERP implementations looked upon the critical success factors from the perspective of their being strategic or tactical (Holland and Light, 1999). Study has also been conducted to find out the critical success factors that are more relevant to ERP projects as compared to a regular IT project or a general project. In this study, it was found that for ERP projects critical success factors are cultural and 
business changes, managing consultants, managing conflicts and staff retention (Skok and Legge, 2002). Some of the studies have been specifically focused on singular dimensions of critical success factors like importance of change management in ERP implementation (Jarrar et al., 2000) and expound on how change management is the crux. After ERP implementation is over, there is a phase of post implementation period and studies have specifically focused on the same (Ifinedo et al, 2010; Zhu et al., 2010). Likewise, there are critical success factors specifically done for ERP upgrades (Olson, Zhao, 2007). Geography centric researches have been done to capture the impact of local factors. For ERP implementations in China, critical success factors were identified explicitly (Guang-hui et al, 2006; Zhang et al, 2003). Likewise, there have been similar studies done for ERP implementations in Mexico (Garcia-Sanchez, Perez-Bernal, 2007) and India (Upadhyay and Dan, 2009). Further studies of critical success factors have been done against a backdrop of classical management theory as well (Bradley, 2008). Over the years, for ERP Implementations, various dimensions, like the barriers (Peng and Nunes, 2010), organization structures (Gallagher and Gallagher, 2010), quality issues (Kumar et al., 2009), communication effects (Yuying and Yanan, 2009), consultant selection (Tsai et al., 2009a), software selection (Tsai et al., 2009b), leadership (Shao et al., 2009), planning and control (Tsai et al., 2009c) etc. have been the object of research. In all these studies, there is a bevy of critical success factors that come into play starting from top management support, goal, objective, vision, user knowledge and training, project management to inter departmental conflicts etc. (Upadhyay and Dan, 2008; Jing and Qiu, 2007; Song et al., 2007; Chou and Chang, 2008; Chen et al., 2009; Baharum et al., 2009).

While on one side, there were these above mentioned ERP applications that were changing the way businesses were being run, concurrently offshoring of IT Services was also picking up and was changing the way IT organizations are run (Davis and Ein-dor, 2006). IT Services were getting offshored and the value chain that delivered services got transformed (Giao et al., 2008). Given the advantages of offshoring, there have been a studies undertaken that have helped develop frameworks and models around offshoring (Soliman, 2003; Tate and Ellram, 2009; Youngdahl and Ramaswamy, 2008), viewpoints on the role of trust in outsourcing (Antoine, 2007), the mindset changes needed (Aydin et al., 2010) and very detailed studies that help understand offshoring better (Jensen, 2009; Chadee and Raman, 2009; Gonzalez et al., 2006; Stratman, 2008).

There are advantages of offshoring but there are the concomitant issues (King, 2008), risks, co-ordination problems (Mirani, 2007) as well. Offshoring is a decision that will be taken by the senior management, but the middle management that has to make it happen will not share the same vision and enthusiasm and can jeopardize offshoring (Lacity and Rottman, 2009). Offshoring is fraught with uncertainty (Clott, 2009). To increase control, some organizations try taking the middle path where offshoring is done but not outsourcing (Preston, 2004; Lampel and Bhalla, 2008). In offshoring, there could be factors like culture, time zone, knowledge, language, infrastructure, offshoring backlash etc. that could jeopardize offshoring (Lacity et al., 2009; Gregory et al., 2009)

So, it can be aptly concluded that both ERP and offshoring are two seminal trends and their importance cannot be undermined. There are organizations that are trying to marry ERP implementations and offshoring. This opens up immense possibilities of gains but at the same time risks get compounded as both ERP implementations and offshoring are fraught with uncertainties. It is in this context that this study has been conducted on critical success factors for offshoring of ERP Implementations.

\section{Research Approach}

This study takes a qualitative and exploratory approach that involves in-depth, semi structured interviews with ERP program managers involved in offshoring to elicit the success factors in offshoring of ERP implementations. Respondents were ERP program managers who had played a key leadership role in ERP implementations involving offshoring. Twelve such ERP experts were interviewed as a part of this study working in different organizations.

Twelve Fortune 500 organizations have been targeted and one response from each gathered. The designation of 12 respondents include general manager, $\mathrm{ClO}$, vice president, assistant vice president, head of IT, country head of IT, senior manager, country CIO, GM projects, head of purchase. Out of 12 respondents, 3 were female managers and 9 male managers. Four managers are with master's degree while 8 are with bachelor's degree. The average experience of the respondents is 17.2 years in the range of 12 years to 25 years. The average combined offshoring and ERP experience of respondents is 14.4 years in the range of 10 years to 21 years. There are 5 respondents, who have the experience working with SAP and Oracle background, 1 has on working with SAP background only, while 6 respondents are having experience working with SAP and other ERP packages. Respondents are having the multi industry experience that includes; 9 in manufacturing, 4 in banking and financial services, 3 in retail and consumer 
products, 3 in energy and utilities, 1 in life science and healthcare and agri-business, 1 in government, 1 dairy and food. Perhaps, it could be conducted with more organizations in different countries, but, it was not possible due to time limit and other constraints.

We used the Switzerland companies for pilot study and would like to continue the further research as India is the prominent offshoring location hence the country scope has been restricted to ERP implementations in outside India, with the offshoring location being India. Further, given the prominence of "offshored outsourced" scenarios vis-a vis "offshored insourced" scenarios, the scope has been restricted to "offshored outsourced" scenarios and not "offshored insourced" scenarios. Lastly, ERP is a generic name that sometimes gets loosely defined to include small business packages as well. Hence, the scope of study has been restricted to include the traditional ERP offerings from the stable of SAP and Oracle. These two companies are the major ERP players and between them control more than 50 per cent of the market.

The questions were open-ended and followed a flow which started with "opening lines" to ascertain conducive research environment for the interview and give assurance on confidentiality of responses, withholding of names etc. After that, introductory background was given, objective of study, and to understand the background of the interviewee. This was followed by the core questions, which went into details and elicited insights and perspectives around critical success factors. Finally, the closing questions were used to summarize the critical success factors and bring closure to the discussion.

Semi structured interviews were recorded using voice recorder. Subsequently the recordings were analyzed and researcher coded the data. Further, the coded data was analyzed and summarized to elicit the critical success factors/themes from each interview. Lastly the critical success factors/themes of the individual interviews were compared and each factor/theme was weighed by counting the number of respondents who expressed the same or similar factors among themes.

To ensure reliability and validity of the findings from interviews, the interviewees were encouraged to compare the interview findings with documents from the organization (monthly status reports, quality gate reports, steering committee minutes etc.). Likewise, member checking was done where results from qualitative study were returned to the participants for verification. An independent ERP expert was involved to review the process and output of the study in the entire process of research.

The duration of each interview was to the tune of an hour. There was an additional follow up round of interview which used to typically last half an hour where interviewees were presented the outcome of the interview.

Also it needs to be highlighted that this qualitative exploratory research that has been undertaken and is the focus of this paper is part of a larger research plan where the subsequent step would be to validate the output of this qualitative study using a quantitative survey based research.

\section{Findings and Discussion}

The study findings have been summarized in ten critical success factors. The critical success factors have come out well and capture a broad spectrum. The list of factors that came out prominently from the in depth and semi structured interviews are given below.

1. Objectives

2. Senior Management

3. Organization Change Management

4. Project Management

5. Project Team Composition

6. People Issues

7. Communication

8. Onsite Offshore Norms

9. Offshoring Partnership

10. Enabling Infrastructure

\section{Objectives}

The objectives set for the ERP offshoring program was one of the upstream factors that came to the most preferred in the respondent's opinion. There has been a need for articulation of strategic and long term objectives at the onset and planning for offshoring is a success factor. The objectives should be ;(1) quantifiable and measurable, (2) comprehensive and should go beyond simple cost arbitration advantage, (3) access to a larger talent pool, focusing on core competency etc. After objective setting, the expectations have to be managed around the objectives. 


\section{Senior Management}

The senior management is a success factor on the side of client. ERP offshoring meets a lot of resistance in an organization. The implications of offshoring could be job cuts and on occasions the junior management and middle management could be working retrograde. In Switzerland, the workplace bonds go deep and it is very difficult to see a colleague being marginalized. Hence, senior management support is a critical success factor. Senior management support has to be very visible as well. Further, the senior management has to be involved in the governance of the ERP offshoring program. Governance cannot be left to the middle management as the middle management will find their workplace relationships restraining them from taking tough decisions.

\section{Organization Change Management}

ERP offshoring changes the way the parts of IT department are run in client organizations. This change has to be planned and executed well. Organization change management cannot be let to happen on its own. It is something that has to be planned in advance and not as an afterthought. Accordingly, the employees need to know what they need to do in the changed environment and this could call for reskilling of the personnel. It is better not to lead anything to assumptions. The IT department has to be restructured to assimilate ERP offshoring.

\section{Project Management}

While project management is a must for any successful project, in case of offshored ERP implementations, there is an extra project management overhead as parts of work have to be split, sent to offshore, monitored, and delivered from offshore. This calls for micro project management so as to ensure that offshoring activities dovetail into the larger ERP implementation project plan. Since offshoring means work will happen remotely, so this calls for standardization of processes and standards. This standardization leads to onsite as well as offshore teams using the same processes, coding standards, documentation standards, naming conventions etc. and thus obviating wrong assumptions and weak practices. In the study, what also came to the fore was that offshoring vendors based in India were more oriented towards PMP framework as compared to Prince2 framework. However, in Switzerland, just like rest of Europe, Prince2 methodologies are also prevalent. Lastly, offshoring calls for two organizations coming together for a common goal. Thus, this calls for good project management at end, the client end as well as offshoring partner's end.

\section{Project Team Composition}

The project team is set of domain skilled people, those, who deliver the ERP offshoring project. For effective services the composition of team working on project is a critical success factor. The cross functional and domain knowledge of the project team is an important aspect for composition. In the interviews conducted, many emphasized on the need for offshore to talk business language. Since it was technical work that was getting offshored, the offshore personnel were mostly technical (and not so much functional) whereas when the requirements were coming from client/onsite, it was from personnel who understood business / functional better and hence were uncomfortable with technical language. Further, even when the vendor personnel had business process knowledge, it had to be grounded in the context of local statutory laws and rules. Another element of team composition is teams ERP package skills in the team. ERP still remains an elusive skill set that commands a lot of premium. The team should be strong in ERP skills. Quality of vendor personnel also plays a role in team composition. The offshore team quality can be lacking on occasions. Offshore normally is an entity that is hidden from client/onsite. In person interaction seldom happens. So to that extent while the vendor personnel getting deputed to onsite are strong as they have to take up customer facing roles at onsite, it is the not so skilled personnel who get staffed at offshore. The perception is that vendors have a tendency to put weak personnel at offshore. Thus, the quality of offshore deliverables gets disputed at times. The team experience is yet another attribute of team composition. There is no substitute for ERP offshoring experience. The experience cannot be bridged by academic studies. It has to be lived and experienced. Knowledge is another aspect of team composition. In ERP offshoring, for offshoring to be effective, the knowledge has to be transitioned from client organization to vendor organization. Knowledge also flows from onsite to offshore. Ensuring the appropriate knowledge levels in the team, knowledge management is important for success. Yet another attribute of team composition is the leaders in the team. The team leads provide leadership at onsite \& offshore and they influence the success of ERP offshoring.

\section{People Issues}

This factor is based on cognition of individual while project team composition was based on professional and knowledge skills based. In the business of rendering services, people issues are important. Offshoring 
of ERP implementation is also a service getting rendered. The fact that in the team getting formed, cultural diversity is invariably there makes culture get a lot of prominence and importance. Cultural respect has to be there in the team and likewise cultural gaps have to be bridged. Cultural gap lead to gaps in understanding of requirements, gaps in importance of deadlines, gaps in workplace expectations etc. and is a critical success factor. The teams coming from different backgrounds, and in many cases team members never seeing their counterparts leads to trust issues. This is yet another determinant of success of ERP offshoring. For people to deliver collectively, it is important that team play is good. When teams are sitting remotely, getting them to synergize as a team is difficult.

\section{Communication}

Communication came up as an important determinant of success. More so, because in an onsite: offshore model, communication with clients happens both in person as well as in remote mode. In case of remote communication between the client team in Switzerland and offshore team in India, the ability to articulate and communicate with the client becomes very important. The offshoring location is India and personnel of offshoring vendors based in India have a fair fluency in English, but not for languages spoken in Switzerland. The requirement for vernacular is important to succeed in Switzerland. The problem gets more compounded as Switzerland is a country of multiple languages. Since, the teams are sitting remotely so ensuring that communication is reaching the relevant personnel in a timely manner is important. The communication plan and flow needs to be in place proactively to ensure this. To buttress communication, there should be periodic visits that ensure that teams meet in person. Likewise audio and video facilities also strengthen the communication between geographically distributed teams. The investment that the organizations are willing to make in communication infrastructure like teleconferences, video conferences, tele-presence etc. helps in making communication strong and effective. Many interviewees felt that communication can be strengthened by ensuring that communication is happening at both formal and informal levels. Informal communication goes about strengthening formal project communication.

\section{Onsite Offshore Norms}

The onsite offshore norms in terms of personnel split between onsite and offshore, the work distribution across onsite and offshore and clear definition of work to be sent offshore are determinants of success. The right split of personnel between onsite and offshore plays a role in success of ERP offshoring. Over offshoring can make the entire program extremely risky. A very heavy onsite can lead to erosion of benefits of offshoring. For successful offshoring, a healthy but lean onsite presence of personnel is required at onsite who can co-ordinate and route requirements and artifacts between client and the offshore team. Likewise, onsite also provides same time zone response and doubles up as a quick response team. So compromising with onsite staffing beyond a certain level is not advisable. Many interviewees were of the opinion that prudence and discretion had to be exercised at the time of deciding what has to be offshored. It was opined by interviewees that it is easier to offshore technical (programming related) work as compared to functional work. Another way of looking at this is that requirement elicitation is best done onsite whereas the downstream work in terms of technical design, coding / configuration, unit testing is best done offshore before the works again gets pushed to onsite for integration testing, user acceptance testing, cutover and go live activities. Some interviewees paraphrased this as business blueprinting, Cut over and Go Live being done onsite whereas realization was done mostly offshore. Further many interviewees were of the opinion that the work that has to be sent offshore should have clarity of requirement, expectation, testing criteria etc. The definition has to be explicit, since, the team will be working remotely and without much interaction with onsite team. To that extent many interviewees felt that the half a day overlap between India and Switzerland makes offshoring easy from Switzerland.

\section{Offshoring Partnership}

The importance of offshoring partner and partnership is a critical success factor for ERP offshoring. The offshoring partner has to be a trusted and experienced partner. It should have experience in handling clients from same geography namely Switzerland in the past. The technology focus of offshoring partner should be aligned with the technological need of the client. Since success of ERP implementations is dependent upon the industry knowledge so the offshoring partner should be experienced in that industry domain. Switzerland, in spite of the small size has leading companies from very different industries banking, insurance, dairy etc. Offshoring is long term arrangement hence the financial stability of the offshoring partner was emphasized for success. The contract that was crafted for offshoring partner also influenced success of offshoring. Contract should be efficient and adapted to the offshoring needs. Further the partner should have a strong human resource pool and strong immigration capabilities. Partner should have the ability to increase the number of personnel and introduce new skills at short notices. One of the reasons, why customers are going in for ERP offshoring is that customers themselves cannot run 
a full-fledged ERP practice and hence scalability is an expectation from partner. Further there are two aspects of scalability - onsite and offshore, the former being especially challenging. Onsite scalability is the capability of the partner to supply and deploy personnel at onsite at short notices with the right visas / work permits. The ability of a partner to get the right work permits for its personnel is important. India is the offshore location and most of the personnel are Indian Passport holders. Indian passport holders need to go through elaborate visa procedures for most of the countries unlike personnel from western countries. So lead time involved becomes more. Further in case of Switzerland, the work permits are issued for a canton within Switzerland and if the vendor personnel sent onsite has to change the canton, elaborate work permit transfer procedures have to be taken up. Also, if the vendor personnel have to stay in Switzerland for long periods running into multiple years the nature of work permit changes. Thus, many times the number of work permits being allowed in canton could be a restrictive number. On account of these additional complications, the immigration capabilities of offshoring partners based in India gets restricted and impacts offshoring of ERP implementations.

\section{Enabling Infrastructure}

The associated enabling infrastructure came forward as a critical success factor for all ERP offshoring activities. The connectivity link between the onsite location in Switzerland and offshore location in India is very important. Both the speed of link and stability of link are important. It is a good practice to have a backup link as well. Companies in Switzerland do not necessarily go in for leased lines and are fine accepting VPN links over internet. The connectivity has to be fast enough otherwise opening document, launching applications etc. from offshore is slow and leads to fall in productivity. Security of the connectivity and offshoring location is another attribute of enabling infrastructure. Client organizations especially those in banking industry, Switzerland being a major hub for banking, insisted on setting up of secure and exclusive work areas at offshore locations. There was a good emphasis on using tools as well. There were tools for enabling collaboration, for project management, technical tools etc. which helped in effective ERP offshoring.

\section{Concluding Remarks}

The research started with the research question, what are the critical success factors for offshoring of ERP implementations. The question has been answered in adequacy and the critical success factors have come out well and are comprehensive in terms of coverage. Table 1 demonstrate the critical success factors of offshoring ERP implementation and who is primary responsible for each factor. It has been noticed from literature that either client or vendor or both are responsible in such programs. It was also intervened during interview that where is the major role of vendor/client/client-vendor. We summarized the results of the interview in the Table 1 and supported them by literature.

Table 1: Critical Success Factors and Responsible Stakeholder

\begin{tabular}{|l|l|l|l|l|l|}
\hline Critical Success factors & $\begin{array}{l}\text { Vendor } \\
\text { Specific }\end{array}$ & $\begin{array}{l}\text { Client } \\
\text { Specific }\end{array}$ & $\begin{array}{l}\text { Vendor and } \\
\text { Client Specific }\end{array}$ & General Recommendation & References \\
\hline Objectives & $\checkmark$ & & Client should have clear objectives & Holland, Light (1999) \\
\hline Senior Management & & $\checkmark$ & Senior management support is essential from client side & Shao et al. (2009) \\
\hline $\begin{array}{l}\text { Organization Change } \\
\text { Management }\end{array}$ & & & Organizations should be ready to adopt the change & Jarrar et al. (2000) \\
\hline Project Management & & $\checkmark$ & Project management should be concern for both & Mirani (2007) \\
\hline $\begin{array}{l}\text { Project Team } \\
\text { Composition }\end{array}$ & & $\checkmark$ & $\begin{array}{l}\text { Right mix of the team members and it is important for } \\
\text { both }\end{array}$ & King (2008) \\
\hline People Issues & & $\checkmark$ & People issues are to be taken care by both & Lacity et al. (2009) \\
\hline Communication & & $\checkmark$ & $\begin{array}{l}\text { Enabling mutual and cross organization communication } \\
\text { is essential for success }\end{array}$ & Yuying, Yanan (2009) \\
\hline Onsite Offshore Norms & & $\checkmark$ & Onsite offshore norms should be followed by both & Zhang et al. (2003) \\
\hline Offshoring Partnership & $\checkmark$ & & Offshoring partnership for long period & Upadhyay, Dan (2009) \\
\hline Enabling Infrastructure & $\checkmark$ & & & Vendor should provide the infrastructure & Lacity et al. (2009) \\
\hline
\end{tabular}


Some factors are more skewed to the client organization namely objectives of offshoring, the senior management of client organization and the organization change management that has to under taken in the client organization. Some factors are more skewed to the vendor organization namely offshoring partnership and the enabling infrastructure that links the vendor organization to the client organization. There are other factors like, project management, project team composition, people issues, communication and onsite offshore norms, which are applicable to both client organization and vendor organization.

As a client organization manager, one has to understand that objectives of offshoring, seniormanagement support and change management are critical success factor for offshoring the ERP implementation. Sharing the objectives of ERP right from beginning in organization will help to manage the change easily where senior management support requires. Being vendor organization manager, one has to dedicate the attention of offshoring partnership and enabling infrastructure for successful offshoring ERP implementation. Both client organization and vendor organization have to work together for project management, people front, communication, norms in order to make it successful. it is the myth that ERP implementation is only vendor's responsibility. Both organizations have to work together with proper communication and cooperation of each other to bring success and synergy while offshoring ERP implementation.

Our research has limitations which are also sources for possible future research directions. The data gathered and analyzed from Switzerland lack the generality of the conclusion. In fact, the conclusion can be more strengthened with the ability of cross county data. Moreover, the further research could also focus on testing on other countries in USA and Europe and comparing the result between them. Although the sample size could be considered a limitation of the study, all attempts were made to ensure its reliability through an elaborate survey design and questionnaire structure. Also, it needs to be highlighted that this qualitative exploratory research that has been undertaken and is the focus of this paper is part of a larger research plan where the subsequent step would be to validate the output of this qualitative study using a quantitative survey based research.

\section{References}

1. Antoine, R. M. B. (2007), "The offshore trust: a catalyst for Development", Journal of Financial Crime, Vol. 14, No. 3, pp. 264-278.

2. Aydin, M. N., Groot, J. D., Hillegersberg, J. V. (2010), "Action readiness and mindset for IT Offshoring", Journal of Enterprise Information Management, Vol. 23, No. 3, pp. 326-349.

3. Baharum, Z., Ngadiman, M. S., Haron, H. (2009), "Critical Factors to Ensure the Successful of OS-ERP Implementation Based on Technical Requirement Point of View", in Proceedings of 3rd Asia International Conference on Modelling \& Simulation, IEEE, Bali, pp. 419-424.

4. Bradley, J. (2008), "Management based critical success factors in the implementation of Enterprise Resource Planning systems", International Journal of Accounting Information Systems, Vol. 9, No. 3, pp. 175-200.

5. Chadee, D., Raman, R. (2009), "International outsourcing of information technology services: Review and future directions", International Marketing Review, Vol. 26, No. 4/5, pp. 411-438.

6. Chen, C. C, Law, C., Yang, S. C. (2009), "Managing ERP Implementation Failure: A Project Management Perspective", IEEE Transactions on Engineering Management, Vol. 56, No. 1, pp. 157-170.

7. Chou, S. W., Chang, Y. C. (2008), "The implementation factors that influence the ERP benefits", Decision Support Systems, Vol. 46, No. 1, pp. 149-157.

8. Clott, C. (2007), "An uncertain future: A preliminary study of offshore outsourcing from the manager's perspective", Management Research News, Vol. 30, No. 7, pp. 476-494.

9. Cooke, D., Gelman, L., Peterson, W. J (2001), "ERP Trends", available at: www.conferenceboard.ca/ documents.asp? rnext=869 (1 April 2012).

10. Davis, G. B., Ein-Dor, P., King, W. R., Torkzadeh, R. (2006), "IT OFFSHORING: History, Prospects and Challenges", Journal of the Association for Information Systems, Vol. 7, No. 11, pp. 770-795.

11. Gallagher, K. P., Gallagher, V. C. (2010), "An exploratory study of Organizing Structures for Post Implementation ERP", in Proceedings of the 43rd Hawaii International Conference on System Sciences, IEEE Computer Society, Koloa, Kauai, $10 \mathrm{p}$.

12. Garcia-Sanchez, N., Perez-Bernal, L. E. (2007), "Determination of Critical Success Factors in Implementing an ERP System: A Field Study in Mexican Enterprises", Information Technology for Development, Vol. 13, No. 3, pp. 293-309.

13. Giao, P. R., Oliveira jr., M. M., Vasconcellos, E. P. G. (2008), "Services Offshoringand Its Strategic Effects on Value Chains", Brazilian Administration Review, Vol. 5, No. 3, pp. 193-209.

14. Gioia, R. (2002), "ERP survey results point to need for higher implementation success", available at: www.robbinsgioia.com/news_events/012802_erp.aspx (1 April 2012). 
15. Gonzalez, R., Gasco, J., Llopis, J. (2006), "Information systems offshore outsourcing: A descriptive analysis, Industrial Management \& Data Systems, Vol. 106, No. 9, pp. 1233-1248.

16. Gregory, R., Prifling, M., Beck, R. (2009), "The role of cultural intelligence for the emergence of negotiated culture in IT offshore outsourcing projects", Information Technology \& People, Vol. 22, No. 3, pp. 223-241.

17. Guang-hui, C., Chun-qing, L., Yun-xiu, S. (2006), "Critical Success Factors for ERP Life Cycle Implementation", Research and Practical Issues of Enterprise Information Systems, Volume 205, pp. 553-562.

18. Holland, C., Light, B. (1999), "A Critical Success Factors Model for ERP Implementation", The Trenches IEEE Software, Vol. 16, No. 3, pp. 30-36.

19. Hunton, J. E., Lippincott, B., Reck J. L. (2003), "Enterprise Resource Planning Systems: comparing firm performance of adopters and nonadopters", International Journal of Accounting Information Systems, Vol. 4, No. 3, pp. 165-184.

20. Ifinedo, P., Rapp, B., Ifinedo, A., Sundberg, K. (2010), "Relationships among ERP post-implementation success constructs: An analysis at the organizational level", Computers in Human Behavior, Vol. 26, No. 5, pp. 1136-1148.

21. Jarrar, Y. F., Al-Mudimigh, A., Zairi, M. (2000) "ERP Implementation Critical Success Factors - The Role and Impact of Business Process Management", available at: http://www.imamu.edu.sa/Scientific_ selections/Documents/IT/ERP-2000-3.pdf (1 April 2012).

22. Jensen, P. D. O. (2009), "A learning perspective on the offshoringof advanced services", Journal of International Management, Vol. 15, No. 2, pp. 181-193.

23. Jing, R., Qiu, X. (2007), "A Study on Critical Success Factors in ERP Systems Implementation", in Proceedings of International Conference on Service Systems and Service Management, IEEE, Chengdu, 6 p.

24. Kaka, N. (2009), "Strenthning India's Offshoring Industry", available at: http://www.mckinseyquarterly. com/Strengthening_Indias_offshoring_industry_2372 (1 April 2012).

25. King, W. R. (2008), "Issues in IS Offshoring", Information Systems Management, Vol. 25, No. 3, pp. $287-289$.

26. Kumar, K., Hillegersberg, J. V. (2000), "Enterprise resource planning: introduction", Communications of the ACM, Vol. 43, No. 4, pp. 22-26.

27. Kumar, M., Suresh, A. V., Prashanth, P. (2009), "Analyzing the Quality Issues in ERP Implementation: A Case Study", in Proceedings of 2nd International Conference on Emerging Trends in Engineering and Technology, IEEE, Nagpur, pp. 759-764.

28. Lacity, M. C., Khan, S. A., Willcocks, L. P. (2009), "A review of the IT outsourcing literature: Insights for practice", Journal of Strategic Information Systems, Vol. 18, No. 3, pp. 130-146.

29. Lacity, M. C., Rottman, J. W. (2009), "Effect of offshore outsourcing of information technology work on client project management", Strategic Outsourcing: An International Journal, Vol. 2, No. 1, pp. 4-26.

30. Lampel, J., Bhalla, A. (2008), "Embracing realism and recognizing choice in IT offshoring initiatives", Business Horizons, Vol. 51, No. 5, pp. 429-440.

31. Mirani, R. (2007), "Procedural coordination and offshored software tasks: Lessons from two case studies", Information \& Management, Vol. 44, No. 2, pp. 216-230.

32. Olson, D. L., Zhao, F. (2007), "ClO's perspectives of Critical Success Factors in ERP Upgrade Projects", Enterprise Information Systems, Vol. 1, No. 1, pp. 129-138.

33. Peng, G. C., Nunes, M. B. (2010), "Interrelated Barriers and Risks Affecting ERP Post Implementation in China", in Proceedings of the 43rd Hawaii International Conference on System Sciences, IEEE Computer Society, Koloa, Kavai, 10 p.

34. Poston, R., Grabski, S. (2001), "Financial impacts of enterprise resource planning implementations", International Journal of Accounting Information Systems, Vol. 2, No. 4, pp. 271-294.

35. Preston, S. (2004), "Lost in Migration: offshore does not mean outsourced", Strategy and Leadership, Vol. 32, No. 6, pp. 32-36.

36. Shao, Z., Feng, Y., Hu, Q., Liu, Y.(2009), "A Conceptual Model for Studying the Influence of Charismatic Leadership on ERP Implementation Lifecycle", in Proceedings of the 42nd Hawaii International Conference on System Sciences, IEEE Computer Society, Big Island, 9 p.

37. Skok, W., Legge, M. (2002), "Evaluating Enterprise Resource Planning (ERP) Systems using an Interpretive Approach", Knowledge and Process Management, Vol. 9, No. 2, pp. 72-82.

38. Soliman, K. H. (2003), "A framework for global IS outsourcing by application service providers", Business Process Management Journal, Vol. 9, No. 6, pp. 735-744.

39. Song, Y., Han, J., Cheng, D., Zhang, Y. (2007), "An Empirical Research on the Impact of CSFs on Adoption of ERP", in Proceedings of International Conference on Wireless Communications, Networking and Mobile Computing, IEEE, Shangai, pp. 6254-6257.

40. Stratman, J. K. (2008), "Facilitating offshoringwith enterprise technologies: Reducing operational friction in governance and production of services", Journal of Operations Management, Vol. 26, No. 2, pp. 275-287. 
41. Tate, W. L., Ellram, L. M. (2009), "Offshore outsourcing: a managerial framework", Journal of Business \& Industrial Marketing, Vol. 24, No. 3/4, pp. 256-268.

42. Tsai, W. H., Lee, P. L., Shen, Y. S., Yang, C. C. (2009b), "The Relationship between ERP Software selection criterion and ERP success", in Proceedings of International Conference on Industrial Engineering and Engineering Management, IEEE, Hong Kong, pp. 2222-2226.

43. Tsai, W. H., Lin, S. J., Lin, W. R., Liu, J. Y. (2009c), "The Relationship between Planning \& Control Risk and ERP Project Success", in Proceedings of International Conference on Industrial Engineering and Engineering Management, IEEE, Hong Kong, pp. 1835-1839.

44. Tsai, W. H., Shen, Y. S., Lee, P. L., Kuo, L. (2009a), "An Empirical Investigation of the Impacts of ERP Consultant Selections and Project Management on ERP IS Success Assessment", in Proceedings of International Conference on Industrial Engineering and Engineering Management, IEEE, Hong Kong, pp. 568-572.

45. Upadhyay, P., Dan, P. K. (2008), "An explorative study to identify the Critical Success Factors for ERP implementation in Indian small and medium scale enterprises", in Proceedings of International Conference on Information Technology, IEEE, Bhubaneswar, pp. 295-299.

46. Upadhyay, P., Dan, P. K. (2009), "ERP in Indian SME's: A Post Implementation Study of the Underlying Critical Success Factors", International Journal of Management Innovation System, Vol. 1, No. 2, pp. $1-10$.

47. Youngdahl, W., Ramaswamy, K. (2008), "Offshoring knowledge and service work: A conceptual model and research agenda", Journal of Operations Management, Vol. 26, No. 2, pp. 212-221.

48. Yuying, Z., Yanan., X. (2009), "Evaluation Indicator System and Weights Research of Communication Effects in ERP Implementation Project", in Porceedings of International Forum on Computer Sciences Technology and Applications, IEEE, Vol. 3, pp. 423-427.

49. Zhang, L., Lee, M. K. O., Zhang, Z., Banerjee, P. (2003), "Critical Success Factors of Enterprise Resource Planning Systems Implementation Success in China", in Proceedings of the 36th Hawaii International Conference on System Sciences, IEEE Computer Society, Big Island, 10 p.

50. Zhu, Y., Li, Y., Wang ,W., Chen, J. (2010), "What leads to post-implementation success of ERP? An empirical study of the Chinese retail industry", International Journal of Information Management, Vol. 30, No. 3, pp. 265-276.

\section{About the authors}

Rajneesh Chauhan is a practitioner with 18 Years in ERP / Offshoring/ Consulting Services. Over his career he has done Service Delivery Management, Program Management and Business Consulting. He has worked across Americas, Europe, Asia-Pacific with many Fortune 500 organizations. By academic qualifications, he is an Electrical Engineer and MBA. Presently, he is a doctoral candidate with IMT Ghaziabd. Author can be contacted at rajneeshchauhan@yahoo.com

Rajeev Dwivedi is an Associate Professor of Strategic Management and Information Technology Strategy. Prior to joining IMT-CDL, he served as an Affiliate Professor of Information Systems at Howe School of Technology Management, Stevens Institute of Technology, USA. He is associated with New Jersey City University, Farleigh Dickinson University, and Vaughn College of Aeronautics in New York Metropolitan area as Adjunct Professor. He received his Doctorate from Indian Institute of Technology (I.I.T.) Delhi on E-Business Strategy. He has over ten years of research and consultancy experience in the field of IT Strategy and E-Business Strategy, and involved actively in various consultancy assignment of government/industry in USA as well in India. Author can be contacted at rajeevdwivedi@gmail.com

Arun Mohan Sherry is the professor and director of IMT-CDL, dean (student affairs \& corporate affairs) of IMT Ghaziabad and chairman (Joint Admission Committee) of Ghaziabad, Nagpur, Hyderabad and Dubai campuses. Dr. Arun Mohan Sherry is a Ph.D., M.Sc. (Gold Medalist), M.Tech. (Computer Science IIT Kharagpur). He is a recipient of Anand Swarup Bhatnagar Gold Medal for securing highest marks in postgraduate examination. He is also a recipient of Brilliant Student Honor by Lions Club in the year 1987 \& 1989; "Rabindranath Tagore Samman"-201 1 for his contribution in the field of Technical Education. He has been Information Technology Consultant of National Hydroelectric Power Corporation Ltd. (A Govt. of India Enterprise) and a Member of the Task Force for strengthening of Information Technology Application in Ministry of Power, Government of India. Author can be contacted at amsherry@imt.edu 